\title{
Prohibition of Torture and Punishment or Inhuman or Degrading Treatment in Criminal Law
}

\author{
Victoria Cristiean \\ “Dimitrie Cantemir" Christian University, Faculty of Juridical and Administrative Sciences, Bucharest, Romania, \\ victoria.cristiean@gmail.com
}

\begin{abstract}
Regulating the ban on torture in the Romanian Criminal Code is the consequence of Romania's accession to the Convention against torture and other cruel, inhuman or degrading treatment or punishment. Incriminating torture, as in international law, is a guarantee that the individual will not be subjected to torture, inhuman or degrading treatment. Through this study, we wanted to highlight the importance of banning torture and inhuman or degrading punishment or treatment, primarily for the good functioning of justice, which implies the exclusion of any violent action, physical or psychological pressure or suffering to obtain information, statements, punishing her or a third person for an act which she has committed or is suspected of having committed, or for any reason based on any form of discrimination.
\end{abstract}

KEYWORDS: discrimination, justice, punishment, torture, violence

\section{Introduction}

In recent years, human rights and freedoms have ceased to be just topics that have been debated in the short term, especially in the press, but have led to extensive mutations in the development of the world's states. The prohibition of torture and inhuman or degrading treatment or punishment are the basis of international and European human rights protection documents. Also, the prohibition of torture and inhuman or degrading treatment or punishment is one of the most important provisions of human rights law. Despite the coherence highlighted by the broad spectrum of international norms that have been adopted to prevent and combat torture, inhuman or degrading punishment or treatment, many reports reflect that they continue to be practiced around the world.

According to art. 1 par. 1 of the Convention against Torture and Other Cruel, Inhuman or Degrading Treatment or Punishment (UN General Assembly 1984), "the term" torture "means any act by which intentional pain, suffering or suffering of a physical or mental nature is caused to a person, in particular with a view to obtaining, from that person or from a person third party, information or confession, to punish her for an act committed by her or a third person to commit, intimidate or pressure her on a third person, or for any other reason based on a form of any discrimination, when such pain or suffering is caused by an agent of the public authority or any other person acting officially, or at the instigation or with the express or tacit consent of such persons."

At regional level, we mention the European Convention on Human Rights which, in art. 3, enshrines one of the most important values of a democratic society. It states that "no one can be subjected to torture, to inhuman or degrading punishment or treatment". Similarly, art. 4 of the Charter of Fundamental Rights of the European Union prohibits torture.

The existence of the rule of law, democratic, is impossible without a minimum guarantee of the essential attributes of the human being.

In the situation where the state fails to guarantee the rights in relation to these types of serious injuries, the discrimination resulting from abuses can lead to persecution. This results when it has particularly serious consequences and the effect transposed into reality is to bring violently to the basic principles of human rights (Bucur 2017, 145).

Torture is forbidden by art. 22 par. 2 of the Constitution of Romania, which states that "no one can be subjected to torture or to any kind of punishment or inhuman or degrading treatment". Also, according to art. 4 par. 1 of the Law no. 275/2006 on the enforcement of the punishment and the measures ordered by the judicial bodies during the criminal proceedings, it is forbidden to subject any person who is serving a punishment to torture, to inhuman or degrading treatment or other illtreatment. 


\section{The regulation of torture in the Romanian Criminal Code}

The regulation of torture in the Romanian Criminal Code is the consequence of Romania's accession to the Convention against Torture and Other Cruel, Inhuman or Degrading Treatment or Punishment (Romania adhered to the Convention on 9 October 1990 by Law No 19 published in the Official Gazette of Romania, Part I, No 112 of 10 October 1990).

Torture is an offense that is part of the group of offenses that impede the achievement of justice, provided in Title IV of the Criminal Code.

Starting from international regulations, and in particular from the provisions of the Convention against torture and other cruel, inhuman or degrading treatment or punishment, the Romanian legislature has criminalized in Art. 282 of the Criminal Code tortures in a similar version to the provisions of the Convention (Popescu, 2012).

\section{We continue to make the definition given by the Criminal Code of Torture:}

Art. 282. (1) The act of a civil servant performing a function involving the exercise of the state authority or of another person acting upon his or her express or tacit consent or instigation to provoke a strong physical or mental suffering: (a) for the purpose of obtaining information or statements from that person or third person; b) for the purpose of punishing her for an act committed by her or a third person or suspected of having committed it; c) in order to intimidate or pressure, or intimidate or put pressure on a third person; d) on grounds based on any form of discrimination, shall be punished by imprisonment from 2 to 7 years and a ban on the exercise of certain rights. (2) If the deed provided in paragraph (1) resulted in bodily injury, the penalty is imprisonment of 3 to 10 years and the prohibition of the exercise of certain rights. (3) Torture resulting in the death of the victim shall be punished by imprisonment from 15 to 25 years and the prohibition of the exercise of certain rights. (4) The attempt to commit the offense provided for in paragraph (1) is punishable. (5) No exceptional circumstances, whatever it may be, be it state of war or threats of war, internal political instability or any other exceptional situation, cannot be invoked to justify torture. Also, the order of the superior or of a public authority cannot be invoked. (6) Torture shall not constitute pain or suffering resulting solely from legal sanctions and which are inherent in or caused by such sanctions.

The offense of torture has a special primary legal object consisting in social relations which concern the good performance of justice, which implies the exclusion of any violent actions, physical or mental suffering or suffering to obtain information, statements, to punish her or a third party person for an act that he has committed or suspected of having committed, or for any reason based on any form of discrimination. The importance of the correctness of civil servants is indicated by the significance of the good activity of the state apparatus they are compiling (Predescu and Hărăstăşanu 2007, 273).

The offense also has a secondary legal object consisting of social relations relating to important personal attributes: physical or mental freedom, dignity, life and bodily integrity and health. The material object of the offense is the body of the person against whom physical or mental suffering is directed. The active subject of the offense is a qualified person in the person of the civil servant or the person acting upon the instigation or with the express or tacit consent of the civil servant.

In order for the civil servant to be an active subject of the offense, he must perform a function involving the exercise of the state authority. If the person directly involved in the offense is a person acting on the instigation or with the express or tacit consent of the civil servant, we may notice that the perpetrator is not of an official quality but acts as a trustee of the offender.

In accordance with the provisions of Article 1751 Penal Code, "civil servant" is the person who, permanently or temporarily, with or without remuneration:

a) exercises attributions and responsibilities established under the law in order to achieve the prerogatives of the legislative, executive or judicial power;

b) exercises a public dignity or a public office of any kind;

c) to carry out, alone or together with other persons, in an autonomous state, another economic operator or a legal person with full or majority state capital or a legal person declared to be of public utility, attributions related to the realization of the object of its activity. 
According to art. 175 par. 2 of the Criminal Code, a civil servant within the meaning of the criminal law is the person exercising a service of public interest for which he has been entrusted by the public authorities or who is under their control or supervision with regard to the fulfillment of the public service. Criminal participation is possible in all its forms, co-sponsored, complicated and instigated. For the existence of the co-author, special quality is required for all co-authors. If this particular quality is lacking, but they have committed acts of direct execution of the deed, they will have the capacity of instigator or complicity (Tănăsescu 2014).

The primary passive subject of the offense is the state (represented by the judicial bodies) as the holder of the socially protected values. Secondary passive subject is the person to whom physical or mental suffering is exerted. From the wording of paragraph 1 it follows that the secondary passive subject of the offense may also be a third person who, by torturing the victim, is intimidated or suffers a moral constraint.

From the point of view of the material element, the crime of torture is carried out, in a typical way, by the action of causing a person pain or strong physical, psychological suffering through violence (Nistoreanu and Boroi 2002, 474). The offense can be accomplished by both action and inaction. For the existence of the offense, it is necessary to meet the following essential requirements:

- physical or mental suffering is strong;

Verifying the fulfillment of the condition that the physical or mental suffering had the effect of causing a strong suffering to the victim lies with the court. If this requirement is not met, we are in the presence of another offense: strike or other violence, abusive behavior, abuse, etc. It does not constitute torture pain or suffering resulting solely from legal sanctions and which are inherent in or caused by such sanctions.

- the act is to be committed in order to obtain information or confessions, punishment, intimidation, discrimination of a person;

- Violence is committed in the exercise of state authority.

The immediate consequence is the provocation of strong physical or mental suffering to determine the victim to have a certain conduct. This action of torture also involves extreme suffering, to the limit of a person's ability to undertake such action.

Causality. Between the act of the perpetrator and the immediate consequence there must be a causal relationship, the physical or psychological suffering suffered by the victim being the consequence of the perpetrator's activity.

From the point of view of the subjective side, some authors (Loghin and Toader 2001, 459) consider that the offense can be committed only with direct intent, because the existence of the offense implies a certain purpose for which the violence is exercised - for obtaining information or confessions, punishment, intimidation, discrimination of a person. Other authors (Boroi 2011, 339; Nistoreanu, Dobrinoiu, Boroi, Pascu, Molnar, Lazar 2001, 488) consider that the intention may be direct or indirect in relation to the production of physical or mental suffering.

It is irrelevant if the information or statements obtained are real or not, as the relevance of whether intimidation or pressures led to the outcome pursued by the perpetrator or whether it is a form or other of discrimination (social or ethnic, political, etc.). In the case of aggravated ways, the resulting consequences must be due to the culprit of the perpetrator. Therefore, the form of guilt in these cases is the obsolete intention.

In accordance with the provisions of paragraph 5: No exceptional circumstances, whatever it may be, whether war or threat of war, internal political instability or any other state of exception, cannot be invoked to justify torture. Also, the order of the superior or of a public authority cannot be invoked. Therefore, in order to remove the guilt, other causes may be invoked: physical or psychological constraint, irresponsibility, involuntary complete whim. As to the purpose pursued by committing the deed, it is not necessary that it has been achieved, being sufficient to have been merely pursued.

The offense of torture goes through both the preparatory and attempted steps. In accordance with the provisions of paragraph 4, attempted the offense provided in paragraph (1) is punishable. The legislator provided for sanctioning the attempt only at par. 1, the type of form, because in the 
aggravated ways the form of guilt is the overt intention, in which case the worse result produced by the fault cannot take the form of the attempt. The offense is consumed instantaneously at the time of the act of incrimination. The offense can also take on the form. In its type, the offense is provided in several normative ways: obtaining testimonies, information, punishment, instigating fear, intimidating or putting pressure on some people. Normative modalities can correspond to a multitude of factual ways. The offense also has two aggravated ways:

- if the deed referred to in paragraph 1 resulted in bodily injury (paragraph 2);

- torture that resulted in the death of the victim (paragraph 3).

In the form of the type, the offense is punished by imprisonment from 2 to 7 years and the prohibition of the exercise of certain rights. The aggravated mode provided by paragraph 2 shall be punished by imprisonment from 3 to 10 years and the prohibition of the exercise of certain rights. The aggravated mode provided by paragraph 3 shall be punished by imprisonment from 15 to 25 years and the prohibition of the exercise of certain rights.

In accordance with the provisions of paragraph 6 , does not constitute torture pain or suffering resulting solely from legal sanctions and which are inherent in or caused by these sanctions.

The criminal action moves ex officio. Jurisdiction in the prosecution stage belongs to the prosecutor. Jurisdiction to resolve the case in the first instance belongs to the court - art. 36 par. 1 lit. of the Code of Criminal Procedure.

\section{Conclusions}

As we have seen, there is an international and European consensus on the prohibition of torture and inhuman or degrading treatment or punishment. Incriminating torture, as in international law, is a guarantee that the individual will not be subjected to torture, inhuman or degrading treatment.

Like the right to life, the prohibition provided in art. 3 of the European Convention on Human Rights requires an official and effective investigation to be made if there are credible allegations of serious ill-treatment by civil servants.

In the judgments handed down by the European Court of Human Rights $(2017,7)$ over the last few years, almost $20 \%$ of the violations found have been the prohibition of torture and inhuman or degrading treatment. Relevant treatments that consist of torture, inhuman or degrading treatment are an alarming phenomenon of today's society, the cause being the intensity and the extent to which they emerge. It is not just a phenomenon of today's society, but a component of it, being characteristic of all historical periods. The magnitude of the phenomenon, especially during armed hostilities, as well as the manifestation of ill-treatment in times of peace, constituting an illegal process of obtaining evidence in the criminal process, have determined the need for harmonized policies at international and regional level.

\section{References}

Boroi, Alexandru. 2011. Criminal Law. The Special Party. According to the new Criminal Code. Bucharest: C.H. Beck Publishing House.

Bucur, Alexandra. 2017. "Some Reflections on the Prohibition of Torture, Inhuman and Degrading Treatment in the Context of Immigration". In Exercising the Right to Non-Discrimination and Equal Opportunities in Contemporary Society - Works of the 11th International Conference on Non-Discrimination and Equality of opportunities NEDES 2017. Bucharest: Pro Universitaria Publishing House.

Loghin, Octavian and Toader, Tudorel. 2001. Romanian Criminal Law. Special part. Bucharest: Şansa Press SRL Publishing House.

Nistoreanu, Gh., V. Dobrinoiu, A. Boroi, I. Pascu, I. Molnar, and V. Lazar. 2001. Criminal Law. Selective Course for the License Exam. Bucharest: Europa Nova Publishing House.

Nistoreanu, Gheorghe and Boroi, Alexandru. 2002. Criminal Law. Selective Course for the Bachelor's Exam. Bucharest: All Beck Publishing House.

Popescu, Agata. 2012. Curtea Europeană a Drepturilor Omului. Rolul şi importanta CEDO în procesul integrării în ordinea juridică comunitară. București: Editura Pro Universitaria.

Predescu, Ovidiu and Hărăstăşanu, Angela. 2007. Criminal Law. The Special Part. Braşov: Omnia Uni S.A.S.T. Publishing House. 
Romanian Penal Code. 1968. Published in the Official Gazette no 79-79 bis of June 21, 1968, republished in the Official Gazette no 55-56 of April 23, 1973, and then in the Official Gazette no 65 of April 16, 1997, with further amendments.

Tănăsescu, Gabriel 2014. Criminal law. The general part, vol. I. Craiova: Sitech Publishing House.

UN General Assembly. 1984. Convention Against Torture and Other Cruel, Inhuman or Degrading Treatment or Punishment, 10 December 1984, adopted and opened for signature by the General Assembly of the United Nations by Resolution 39/46 of 10 December 1984, which entered into force on 26 June 1987 in accordance with the provisions of Article 27 paragraph 1.

European Court of Human Rights. 2017. The European Court of Human Rights in Facts \& Figures, 2016, Human Rights, March 2017 European Court of Human Rights Public Relations Unit F-67075 Strasbourg Cedex, p.7. 